I6 a 18 de outubro de 2019 - Campinas | Brasil

\title{
Placas Planas Magnesianas Aditivadas com Sílica da Casca do Arroz
}

\section{Anderson P. M. Marinho*, Carlos E. M. Gomes.}

\section{Resumo}

O presente projeto de iniciação científica teve como objetivo o desenvolvimento da primeira placa plana à base de óxido de magnésio no Brasil, avaliando a caracterização física e o desempenho mecânico desta comparativamente às placas de Cimento Portland atualmente produzidas no Brasil. Para tal, empregou-se um aglomerante alternativo derivado de rochas magnesianas conhecido como Cimento Sorel, que possui propriedades similares ao cimento Portland, com desempenho avaliado conforme a norma NBR15498/2016 - Placa de Fibrocimento sem Amianto - Requisitos e Métodos de Ensaio, possibilitando a classificação destas placas. Com a realização deste estudo, espera- se difundir o uso das placas magnesianas no pais, ocasionando avanços técnicos e econômicos para a construção civil brasileira, uma vez que o compósito avaliado apresenta custo reduzido quando comparado com outras placas de fibrocimento.

\section{Palavras-chave:}

Cimento Magnesiano, Cimento Sorel, Sílica da Casca do Arroz

\section{Introdução}

As placas cimentícias tem ganhado destaque na construção civil (principalmente na construção a seco, como Light Steel Frame e Dry-Wall) devido a facilidade e velocidade de sua implementação, no Brasil ainda há a predominância de processos artesanais com utilização ínfima destas placas.

Este estudo foi realizado com a proposta de utilizar-se cimento a base de Óxido de Magnésio (cimento magnesiano) para a fabricação destas placas, pois este apresenta propriedades similares ao cimento Portland com o diferencial de permitir a adição de fibras sintéticas (fibras de vidro, PP, PVA, etc...), adotou-se a adição da Sílica da Casca do Arroz (SCA) pois esta exerce influência em várias características do concreto, incluindo a velocidade de desenvolvimento da resistência do mesmo, possibilitando uma melhora significativa na qualidade do concreto.

\section{Resultados e Discussão}

O projeto foi divido em duas etapas, a primeira composta pela moldagem das placas com diferentes concentrações de Cloreto de Magnésio (20\% e $40 \%$ ) e de SCA ( $0 \%$, $5 \%$ e $10 \%$ ), variando também a relação de Carbonetos de Cálcio por Óxido de Magnésio obtemos um total de 12 composições distintas. Cada uma destas placas foi subdividida em três corpos de provas, um destes é submetido a um processo de saturação, enquanto os demais permanecem secos.

A segunda etapa foi referente a realização dos ensaios mecânicos de resistência à tração na flexão, conforme procedimento descrito na norma NBR15498, estes foram realizados 28 dias após a moldagem dos corpos de prova.

\section{Conclusões}

Com a realização deste estudo foi possível notar que, mantendo a mesma quantidade de Óxido de Magnésio, Carbonato de Cálcio e de SCA, os corpos de prova moldados com maiores quantidades de Cloreto de Magnésio (40\%) apresentaram valores superiores de resistência à tração quando comparados com os corpos de prova moldados com concentração de $20 \%$ deste mesmo sal.

Nota-se também que para uma mesma quantidade de sal e de SCA, os corpos de prova moldados com concentrações de Óxido de Magnésio e de Carbonato de Cálcio de, respectivamente, 25\% e 75\% apresentaram resistência à tração superior à dos corpos de prova moldados com concentrações de $15 \%$ e $85 \%$.

Por último, foi possível observar que a presença de SCA na composição (5\% e $10 \%)$ provocou aumento significativo na resistência dos corpos de prova quando comparados com as placas que não apresentavam este material, entretanto, não ocorreu diferença considerável de resistência entre estes.

\footnotetext{
${ }^{1}$ MISRA, A. K; MATHUR, R. Magnesium Oxychloride Cement Concrete. Bull Mater. Sci. V. 30, n. 3, p. 239-246, 2007.

2 GOMES, C. E. M; CAMARINI, G. NOCMAT. Magnesium Oxysulfate Fiberciment, 14th International Conference on Non Conventional Construction Materials and Technologies - João Pessoa/Brasil, 2013. Key Engineering Materials, v. 600, p. 308-3018, 2014.

3 GOMES, C. E. M. Alternative Binder for Fibercement Building Materials. Advanced Materials Research, v. 753-755, p. 616-622.2013
} 